Web Jurnal:

http://ejournal.kemenperin.go.id/jli

\title{
Powderisasi timah murni menggunakan metode atomisasi gas - satu nosel gas
}

\section{Powderization of tin by single gas nozzle - gas atomization method}

\author{
Abdul Basyir*, Didik Aryanto, Agus Sukarto Wismogroho, dan Wahyu Bambang Widayatno \\ Pusat Penelitian Fisika, Lembaga Ilmu Pengetahuan Indonesia \\ Kawasan PUSPIPTEK, Gd. 440 - 442, Kota Tangerang Selatan, Provinsi Banten, 15314, Indonesia \\ * e-mail: abdulbasyir037@gmail.com
}

\begin{tabular}{l}
\hline INFO ARTIKEL \\
\hline Sejarah artikel: \\
Diterima: \\
3 Maret 2020 \\
Direvisi: \\
28 November 2020 \\
Diterbitkan: \\
28 Desember 2020
\end{tabular}

Kata kunci:

powderisasi;

atomisasi gas;

timah

\begin{abstract}
ABSTRAK
Metode yang dapat digunakan untuk menghasilkan powder adalah atomisasi gas. Desain dari atomisasi gas akan berpengaruh terhadap karakter powder yang dihasilkan. Powder timah dapat digunakan sebagai bahan utama dalam pembuatan pasta solder, timah kimia ( $\mathrm{SnO}$ dan $\mathrm{SnCl}$ ), piroteknik, dan lain sebagainya. Tujuan penelitian untuk menganalisis pengaruh sudut nosel gas terhadap kuantitas output powder yang dihasilkan, distribusi ukuran powder, morfologi, dan fasa powder dari sudut nosel yang menghasilkan output powder paling tinggi. Penelitian pembuatan powder timah melalui metode atomisasi gas menggunakan satu nosel gas yang berbentuk tabung dengan diameter $0.5 \mathrm{~cm}$. Sudut atomisasi (sudut antara nosel gas dengan lobang dari ruang peleburan timah) dengan dua perlakuan yakni $0^{\circ}$ dan $5^{\circ}$, sedangkan ruang penampungan powder tersusun secara horizontal. Berdasarkan hasil eksperimen, desain powderisasi dengan sudut atomisasi $5^{\circ}$ menghasilkan output powder timah, 1,3 kali lebih banyak daripada sudut atomisasi $0^{\circ}$. Powder timah yang dihasilkan dari sudut atomisasi $5^{\circ}$ terdistribusi dalam ukuran $<37 \mu \mathrm{m}$ sebanyak $29,68 \%$ dan ukuran 37 - $150 \mu$ m sebanyak 70,32\%, dengan bentuk yang tidak teratur, dan tidak ditemukan fasa oksida pada semua ukuran partikel.
\end{abstract}

\begin{abstract}
One of the methods for producing powder is atomization gas, and where the design of gas atomization will affect the character of powder output. In this research, the tin powder was generated from gas atomization with a single gas nozzle design, and where the length of the nozzle about $0.5 \mathrm{~cm}$. Furthermore, the single nozzle gas was arranged with an angle of $0^{\circ}$ and $5^{\circ}$ for each experiment. While the powder storage chamber was arranged horizontally. This research was to analyze of gas nozzle angle effect on the quantity of powder output, and especially this research to analyze the morphology, phase, and size distribution of powder from gas atomization design - single nozzle gas with a high-efficiency angle. Based on experiment data, gas atomization with a gas nozzle angle of $5^{\circ}$ has generated 1.3 times tin powder output greater than a gas nozzle angle of $0^{\circ}$. The best design generates powder with a size of $0-37 \mu \mathrm{m}$ (29.68\%) and 37 - $150 \mu \mathrm{m}(70.32 \%)$, consists of irregular shape dominant, and composes of single-phase, tin, without tin oxide existence.
\end{abstract}

(C) 2020 Penulis. Dipublikasikan oleh Baristand Industri Padang. Akses terbuka dibawah lisensi CC BY-NC-SA
Keywords:

powderization; tin timah terbesar kedua di dunia (Champion and Britt, 2018). Data tersebut menunjukkan bahwa ada potensi besar untuk mengembangkan produk hilir dari timah. Produk hilir timah yang paling banyak digunakan (International Tin Assocition (ITA)) adalah untuk aplikasi solder (sebesar 47\%), diikuti oleh kimia (18\%), tin plate $(14 \%)$, dan sisanya untuk aplikasi lain 
(Mulqueen and Pearce, 2018). Salah satu jenis solder yang digunakan adalah solder pasta dengan powder timah merupakan bahan baku utama $(>80 \%)$ dalam campuran solder tersebut. Powder timah yang digunakan adalah powder timah dengan kemurnian tinggi, berukuran kecil $(<40 \mu \mathrm{m})$, dan mempunyai distribusi ukuran yang sempit (Li et al., 2019).

Teknologi untuk menghasilkan powder antara lain teknologi atomisasi, melalui proses kimiawi, distilasi, granulasi-sintering-deoksidasi, dan proses mekanik (Antony and Reddy, 2003; Islam et al., 2019; Li et al., 2018; Sun et al., 2016), dimana teknologi atomisasi terdiri dari beberapa jenis media, seperti atomisasi sentrifugal, atomisasi gas, atomisasi air, atomisasi minyak, atomisasi plasma, dan metode atomisasi yang lain (Neikov, 2008; Sun et al., 2017). Hasil penelitian Wismogroho dkk. di Pusat Penelitian Fisika pada tahun 2018 dengan menggunakan atomisasi sentrifugal menghasilkan powder timah berukuran $<40 \mu \mathrm{m}$, namun persentase output terhadap input masih rendah, hanya mencapai $50 \%$. Selain itu proses powderisasi dengan menggunakan teknologi ini kurang efektif karena piringan sentrifugal yang digunakan untuk melakukan atomisasi timah mengalami over heat dengan sangat cepat. Oleh karena itu, perlu dilakukan proses atomisasi dengan menggunakan media lain.

Atomisasi air merupakan metode atomisasi yang ekonomis dalam segi proses, namun metode ini kurang mampu menghasilkan powder yang murni (tanpa oksidasi) dan berbentuk bulat (Dunkley, 1986; Wisnu, 2019). Salah satu metode atomisasi yang dapat menghasilkan powder berkualitas adalah atomisasi gas dan atomisasi plasma, namun dibandingkan dengan atomisasi plasma, teknologi atomisasi gas cenderung lebih sederhana, sehingga memiliki peluang yang lebih besar dalam menghasilkan powder secara ekonomis (Entezarian et al., 1996).

Teknologi atomisasi gas mempunyai banyak metode dan terus mengalami perkembangan seperti metode kombinasi antara centrifugal hydraulic atomization dan gas atomization, metode electrode induction gas atomization, metode pressure gas atomizer, metode close-coupled gas atomization, metode cold and hot gas atomization, dan lain sebagainya (Ciftci et al., 2018; Ding et al., 2017; Lv et al., 2019; Park et al., 2019). Kelima metode atomisasi gas diatas mempunyai desain yang tidak sederhana.

Penelitian ini melakukan metode atomisasi gas yang sederhana menggunakan satu nosel gas berbentuk tabung dengan dua sudut atomisasi yang berbeda. Desain mesin atomisasi yang dibuat adalah langsung mengarahkan mulut lobang nosel gas kearah lobang dari aliran leburan timah (hanya dalam satu arah dan satu sudut), dengan menggunakan tekanan yang tinggi, diatas 10 bar. Penelitian atomisasi gas dengan desain yang berbeda menunjukkan bahwa semakin tinggi tekanan, maka ukuran powder yang dihasilkan akan semakin kecil (Hussain et al., 2020). Oleh karena itu, diharapkan desain sederhana dengan aliran gas bertekanan tinggi ini dapat meningkatkan persentasi output terhadap input powder, dan ukuran powder yang dihasilkan semakin kecil, serta tidak terbentuk oksidasi.

\section{Metode}

Peralatan atomisasi gas terdiri dari tiga komponen utama yaitu ruang peleburan, nosel gas (ruang atomisasi), dan ruang penampungan. Ruang peleburan didesain agar mampu mengalirkan timah hasil peleburan dengan baik dan terbuat dari material dengan titik lebur jauh lebih tinggi dari titik lebur timah. Ruang peleburan dipasang alat pemanas untuk mengatur suhu pada ruang peleburan. Suhu ruang peleburan ini diatur sebesar $348^{\circ} \mathrm{C}(1.5 \mathrm{kali}$ titik lebur timah; titik lebur timah adalah $232{ }^{\circ} \mathrm{C}$ ). Hal ini dilakukan agar timah dapat melebur dengan cepat dan mengalir dengan lancar menuju ke ruang atomisasi.

Adapun lubang dari ruang peleburan, tempat leburan timah mengalir menuju ruang atomisasi ditutup dengan logam yang mempunyai titik lebur $>$ dari titik lebur timah. Hal ini berfungsi untuk menahan leburan timah agak tidak mengalir secara parsial, namun setelah leburan timah melebur secara keseluruhan, baru dialirkan ke ruang atomisasi.

Nosel gas dengan diameter $0.5 \mathrm{~cm}$ diletakkan tepat didepan dan/atau dibawah dari mulut nosel dari ruang peleburan timah. Nosel gas ini terhubung dengan kompresor gas yang tekanan-nya telah diatur sebesar 7 bar. Area pertemuan antara nosel gas dengan mulut nosel ruang peleburan ini disebut dengan area atomisasi. Didepan area ini diletakkan ruang penampungan powder yang memanjang secara horizontal sepanjang $200 \mathrm{~cm}$. Ketika suhu ruang peleburan telah mencapai suhu 348 ${ }^{\circ} \mathrm{C}$, maka timah padat dimasukkan kedalam ruang peleburan tersebut. Timah padat ini merupakan produksi dari PT. Timah Tbk. yang berbentuk granular berwarna putih mengkilap (Gambar 1).

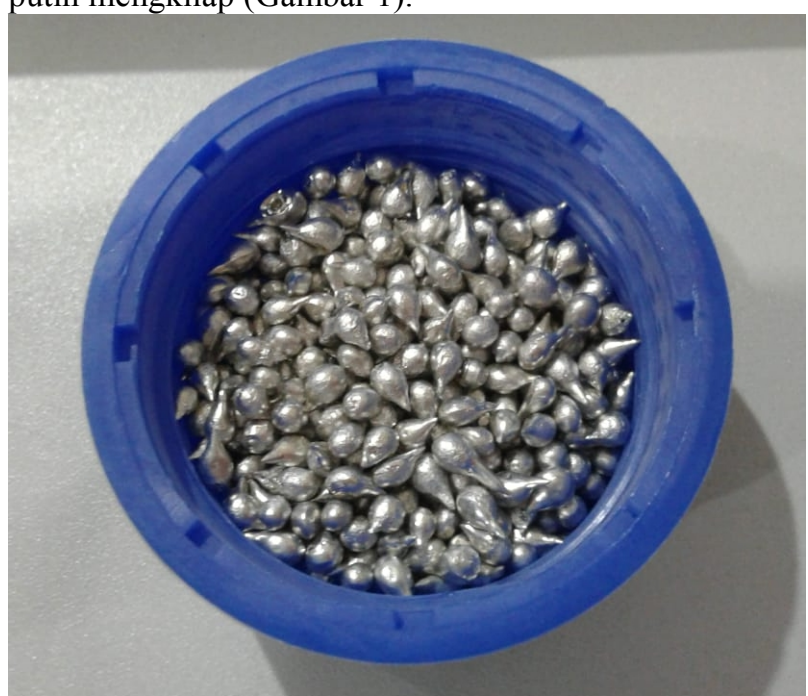

Gambar 1. Morfologi dari timah padat yang digunakan dalam penelitian ini

Setelah timah padat melebur secara menyeluruh, maka gas dialirkan melalui pipa kompresor menuju nosel gas dengan tekanan sebesar 7 bar. Nilai tekanan ini disesuaikan dengan kecepatan dan volume dari leburan timah yang mengalir atau disesuaikan dengan diameter dari mulut nosel ruang peleburan $(0.5 \mathrm{~cm})$, sehingga semakin kecil peluang dari timah lebur untuk lolos dari tumbukan gas saat atomisasi. Batangan penutup lubang mulut nosel ruang peleburan kemudian ditarik dan/atau 
dilepaskan, sehingga timah mulai mengalir menuju area atomisasi dan proses atomisasi timah terjadi.

Variasi perlakuan dalam penelitian dilakukan pada sudut antara nosel gas dengan lobang dari ruang peleburan timah. Perlakuan penelitian pada sudut $0^{\circ}$ dan $5^{\circ}$ (desain Gambar 2). Efisiensi dari desain dihitung berdasarkan persentase output terhadap input dari powder timah yang dihasilkan. Powder dari desain dengan efisiensi terbaik akan diukur distribusi ukuran dan fasa-nya. Selain itu pada powder berukuran $<37 \mu \mathrm{m}$ akan di analisis densitas dan morfologinya. Distribusi dari powder yang dihasilkan akan diukur dan/atau disaring menggunakan saringan 100 (ukuran 74 - $149 \mu \mathrm{m}$ ), 200 (ukuran 37 - $74 \mu \mathrm{m}$ ), 400 (ukuran 25 $37 \mu \mathrm{m}$ ), dan 500 mesh (ukuran $0-25 \mu \mathrm{m}$ ).

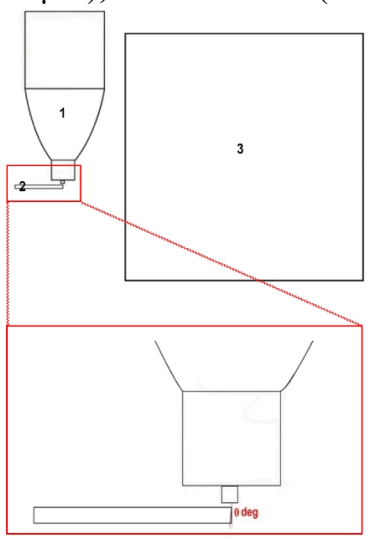

(a)

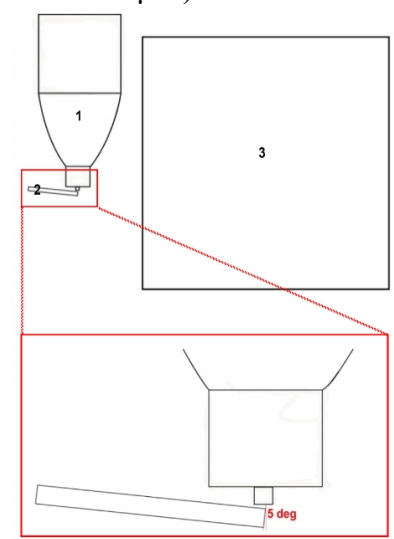

(b)
Gambar 2. Desain dari posisi nosel gas terhadap mulut nosel ruang peleburan dengan sudut (a) $0^{\circ}$.dan (b) $5^{\circ}$, dengan (1) ruang peleburan timah, (2) nosel gas, dan (3) ruang penampungan powder

Pengujian fasa dilakukan menggunakan alat X-Ray Diffraction (XRD) Rigaku Smartlab with $\mathrm{Cu}$ K-beta $\mathrm{X}$ ray tube $(40 \mathrm{kV}, 30 \mathrm{~mA})$, sedangkan pengujian morfologi dilakukan dengan alat Scanning Electron Microscope (SEM) Hitachi SU-3500 (20 kV). Pengukuran densitas dengan piknometer (IWAKI $5 \mathrm{ml}$ ). Proses ini dilakukan untuk membandingkan densitas dari powder timah yang dihasilkan dari penelitian ini dengan densitas powder timah komersil dari Pubchem yaitu $7.31 \mathrm{~g} / \mathrm{cm}^{3}$. Pengukuran densitas tersebut dilakukan mengikuti persamaan (1) (Basyir et al., 2020a).

$$
\rho_{\text {powder }}=\rho_{\text {air }} \frac{\left(m_{3}-m_{1}\right)}{\left(m_{2}-m_{1}\right)-\left(m_{4}-m_{3}\right)}
$$

$\mathrm{m}_{1}$ adalah massa dari piknometer $(\mathrm{g}), \mathrm{m}_{2}$ adalah massa dari piknometer dan air $(\mathrm{g}), \mathrm{m}_{3}$ adalah massa dari piknometer dan powder $(\mathrm{g})$, dan $\mathrm{m}_{4}$ adalah massa dari piknometer + air + powder $(\mathrm{g})$. Setiap massa tersebut diukur sebanyak lima kali, dan nilai rata-rata dari massa tersebut akan diinput kedalam persamaan (1).

Selanjutnya dilakukan simulasi aliran gas dari nosel gas untuk melihat efek sudut terhadap distribusi aliran gas. Dimana simulasi numerik ini dilakukan menggunakan software Fluid Flow (CFX) - Ansys 17.1.

\section{Hasil dan pembahasan}

Proses powderisasi dengan atomisasi gas menggunakan sudut nosel gas $0^{\circ}$ dan $5^{\circ}$ (dilihat pada tabel 1). Metode atomisasi gas dengan nosel gas sudut $0^{\circ}$ menghasilkan output powder timah antara $69-70 \%$ dari input, sedangkan gas nosel dengan sudut $5^{\circ}$ dapat menghasilkan output sebanyak $87-88 \%$ dari input.

Tabel 1.

Hasil output dari powderisasi timah menggunakan metode atomisasi gas - satu nosel gas pada sudut $0^{\circ}$ dan $5^{\circ}$

\begin{tabular}{llllll}
\hline & \multicolumn{4}{l}{ Parameter Atomisasi Gas } & \\
\cline { 2 - 4 } No & $\begin{array}{l}\text { Suhu } \\
\text { Peleburan } \\
\left({ }^{\circ} \mathrm{C}\right)\end{array}$ & $\begin{array}{l}\text { Tekanan } \\
\text { Gas } \\
(\text { Bar })\end{array}$ & $\begin{array}{l}\text { Sudut } \\
\text { Nosel } \\
\text { Gas }\end{array}$ & $\begin{array}{l}\text { Input } \\
(\mathrm{g})\end{array}$ & $\begin{array}{l}\text { Output } \\
(\mathrm{g})\end{array}$ \\
\hline 1 & 348 & 7 & $0^{\circ}$ & 500 & 350 \\
2 & 348 & 7 & $0^{\circ}$ & 500 & 345 \\
3 & 348 & 7 & $5^{\circ}$ & 500 & 440 \\
4 & 348 & 7 & $5^{\circ}$ & 500 & 433 \\
\hline
\end{tabular}

Gambar 3 (a-c) menunjukkan distribusi aliran gas yang dihasilkan dari sudut $0^{\circ}$ pada saat (a) awal keluar dari lobang nosel gas, (b) menuju dan menumbuk ruang penampungan powder, dan (c) melewati ruang penampungan powder. Gambar 3 (d-f) merupakan distribusi aliran gas yang dihasilkan dari sudut $5^{\circ}$ pada saat (a) awal keluar dari lobang nosel gas, (b) menuju dan menumbuk ruang penampungan powder, dan (c) melewati ruang penampungan powder.

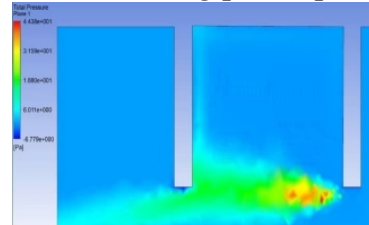

(a)

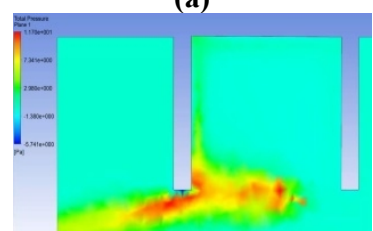

(b)

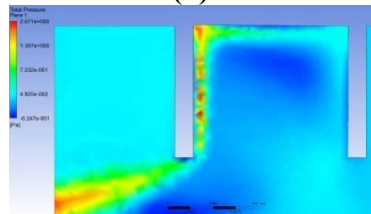

(c)

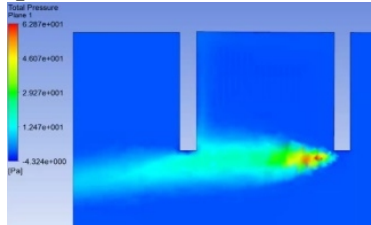

(d)

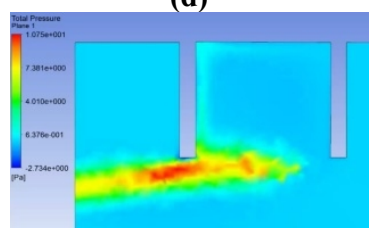

(e)

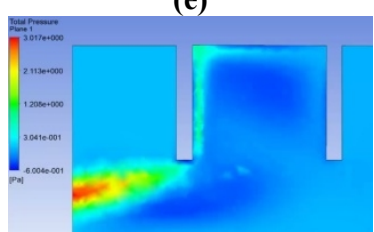

(f)
Gambar 3. Simulasi (a-c) Distribusi aliran gas yang dihasilkan dari sudut $0^{\circ}$ antara nosel gas dengan mulut nosel ruang peleburan dan (d-f) Distribusi aliran gas yang dihasilkan dari sudut $5^{\circ}$ antara nosel gas dengan mulut nosel ruang peleburan

Distribusi aliran gas pada Gambar 3 (a-c) dan (d-f), menunjukkan bahwa aliran gas dengan sudut $5^{\circ}$ lebih banyak terdistribusi ke arah bagian bawah dan/atau masuk kedalam ruang penampungan powder, dari terdistribusi kebagian atas. Aliran gas dengan sudut $0^{\circ}$ terdistribusi pada bagian bawah dan atas penampungan powder dengan perbandingan yang hampir sama, sehingga ada sebagian powder yang dihasilkan dari 
proses ini tidak masuk dan tidak terdorong kedalam ruang penampungan powder, melainkan terhambur keluar dari ruang penampungan powder, terutama powder yang mempunyai ukuran $<37$ mikron. Hal inilah yang menyebabkan sudut antara nosel gas terhadap mulut nosel ruang peleburan sebesar $5^{\circ}$ dapat menghasilkan output, 1,3 kali lebih banyak daripada sudut $0^{\circ}$.

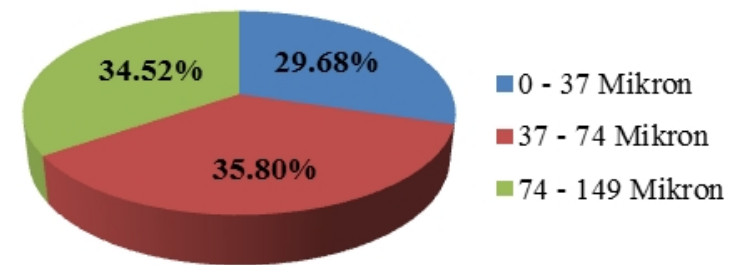

Gambar 4. Distribusi ukuran dari output powder timah yang dihasilkan dari metode atomisasi gas - satu nosel gas dengan sudut $5^{\circ}$ dengan input 500 gram

Powder yang dihasilkan dari desain atomisasi gas dengan sudut $5^{\circ}$ dilakukan pengukuran distribusi ukuran powder dan fasa. Pengukuran distribusi ukuran dan fasa hanya dilakukan pada powder ini, karena desain mampu menghasilkan efisiensi output terhadap input lebih besar. Gambar 4 menunjukkan bahwa powder timah yang dihasilkan mempunyai ukuran partikel dari $0-149 \mu \mathrm{m}$, dengan rincian: powder timah berukuran $0-37 \mu \mathrm{m}$ terdistribusi sebanyak 30\% (atau 132 gram); berukuran $37-74 \mu \mathrm{m}$ terdistribusi sebanyak 36\% (atau 158 gram) berukuran; dan berukuran $74-149 \mu \mathrm{m}$ terdistribusi sebanyak 34\% (atau 150 gram) (Gambar 4). Data tersebut menunjukkan bahwa kuantitas antar kelompok ukuran partikel powder hanya selisih $1-6 \%$. Perbedaan ukuran powder yang dihasilkan tersebut dikarenakan kuantitas distribusi tekanan gas dalam menumbuk leburan timah tidak merata, berubah terhadap waktu (transient flow), sehingga mempengaruhi distribusi dari partikel powder timah yang teratomisasi. Area distribusi gas dengan nilai tekanan yang lebih tinggi ketika menumbuk leburan timah akan menghasilkan partikel powder timah dengan ukuran yang lebih kecil (Akkas and Boz, 2019).

Distribusi ukuran partikel powder timah sebanyak 29,68\% memenuhi spesifikasi ukuran untuk bahan baku aplikasi solder pasta dan tracer projectile (IPC J-STD005A, 2012), sedangkan distribusi sebanyak 35,80\% dan $34,52 \%$ dapat digunakan untuk aplikasi kimia seperti untuk pembuatan $\mathrm{SnO}_{2}$ dan $\mathrm{SnS}_{2}$ (Bai, 2009; Xiao and Zhang, 2008), sehingga tidak ada powder timah yang dihasilkan menjadi limbah. Pembuatan tracer projectile dari powder timah berukuran $<37 \mu$ m dan pembuatan $\mathrm{SnO}_{2}$ dan $\mathrm{SnCl}$ dari powder timah berukuran $>37 \mu \mathrm{m}$ telah berhasil kami lakukan di Pusat Penelitian Fisika LIPI (Basyir et al., 2020b).

Berdasarkan hasil XRD (Gambar 5), powder yang dihasilkan pada ukuran $0-25 \mu \mathrm{m}, 25-37 \mu \mathrm{m}, 37-74$ $\mu \mathrm{m}$, dan $74-149 \mu \mathrm{m}$ terbentuk fasa timah (PDF Card: 00-004-0673), tidak terbentuk fasa timah oksida. Hal ini menunjukkan bahwa powder timah yang dihasilkan tidak teroksidasi pada semua jenis ukuran. Pengukuran ini dilakukan pada semua jenis ukuran powder, untuk memastikan pada semua ukuran powder tidak terdapat fasa timah oksida. Hal ini karena semakin besar ukuran powder, maka konsentrasi oksigen akan semakin meningkat, sehingga kemungkinan terjadinya oksidasi akan semakin besar (Nobari and St-Laurent, 2016).

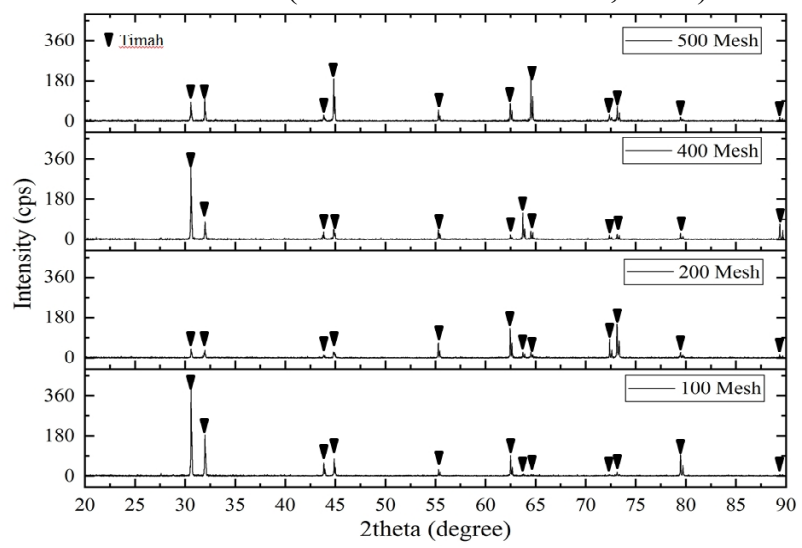

Gambar 5. Hasil uji XRD terhadap sampel dari output powder yang dihasilkan dari metode atomisasi gas - satu nosel gas dengan sudut $5^{\circ}$

Tabel 2.

Parameter input untuk penghitungan densitas dari powder timah yang dihasilkan

\begin{tabular}{|c|c|c|c|c|}
\hline $\begin{array}{l}\text { Pengukuran } \\
\text { ke-* }\end{array}$ & $\mathrm{m}_{1}(\mathrm{~g})$ & $\mathrm{m}_{2}(\mathrm{~g})$ & $\mathrm{m}_{3}(\mathrm{~g})$ & $\mathrm{m}_{4}(\mathrm{~g})$ \\
\hline 1 & 12,399 & 17,624 & 21,411 & 25,181 \\
\hline 2 & 12,402 & 17,624 & 21,410 & 25,182 \\
\hline 3 & 12,403 & 17,624 & 21,409 & 25,183 \\
\hline 4 & 12,401 & 17,624 & 21,409 & 25,183 \\
\hline 5 & 12,402 & 17,623 & 21,408 & 25,182 \\
\hline Rata-Rata & 12,401 & 17,624 & 21,409 & 25,182 \\
\hline
\end{tabular}

$$
\begin{aligned}
& \rho_{\text {powder }}=0.996 \frac{(21.409-12.401)}{(17.624-12.401)-(25.182-21.409]} \\
& \rho_{\text {powder }}=6.192\left(\mathrm{gr}^{\mathrm{r}} / \mathrm{cm}^{3}\right)
\end{aligned}
$$

Pengukuran densitas dan morfologi dilakukan pada powder yang berukuran $<37 \mu \mathrm{m}$ karena untuk aplikasi solder pasta, ukuran powder maksimal yang banyak digunakan adalah $38 \mu \mathrm{m}$ (solder pasta tipe 4 - 6) (Bastow, 2017), dimana semakin kecil ukuran partikel powder untuk solder pasta, maka performa solder pasta yang dihasilkan akan semakin baik (Krammer et al., 2018; Lentz, 2019). Pengukuran morfologi untuk melihat bentuk dari partikel powder timah yang dihasilkan, karena bentuk partikel yang baik untuk aplikasi solder pasta adalah berbentuk bulat (Zhang et al., 2020).

Densitas dari powder timah yang dihasilkan dari sudut $5^{\circ}$ adalah $\pm 6,2 \mathrm{~g} / \mathrm{cm}^{3}$ atau sekitar $86 \%$ dari densitas powder timah komersil (tabel 2 dan persamaan (2) dan (3)). Penurunan densitas dari powder timah tersebut dikarenakan bentuk partikel powder timah yang dihasilkan dominan berbentuk tidak teratur, sehingga susunan antar partikel timah kurang rapat. Hal ini dapat dilihat dari hasil pengujian SEM, hanya sedikit yang berbentuk bulat (Gambar 6). 
Berdasarkan perhitungan menggunakan data pengujian dari 3D Optical Microscope dengan menggunakan sampel powder timah, diketahui bahwa rasio partikel timah yang berbentuk bulat jauh lebih sedikit daripada partikel timah yang berbentuk tidak bulat yaitu 0,05 (Basyir et al., 2020a). Disetiap 100 partikel timah yang tidak berbentuk bulat, terdapat 5 partikel timah yang berbentuk bulat. Data ini mengindikasikan bahwa, dari $30 \%$ powder timah yang berukuran $0-37 \mu \mathrm{m}$, terdapat $1,5 \%$ (setara dengan 2 gram) yang mempunyai bentuk bulat dan berukuran 0 $37 \mu \mathrm{m}$. Partikel powder timah untuk semua ukuran yang berbentuk bulat dihasilkan sebanyak 5\% (setara dengan 22 gram).

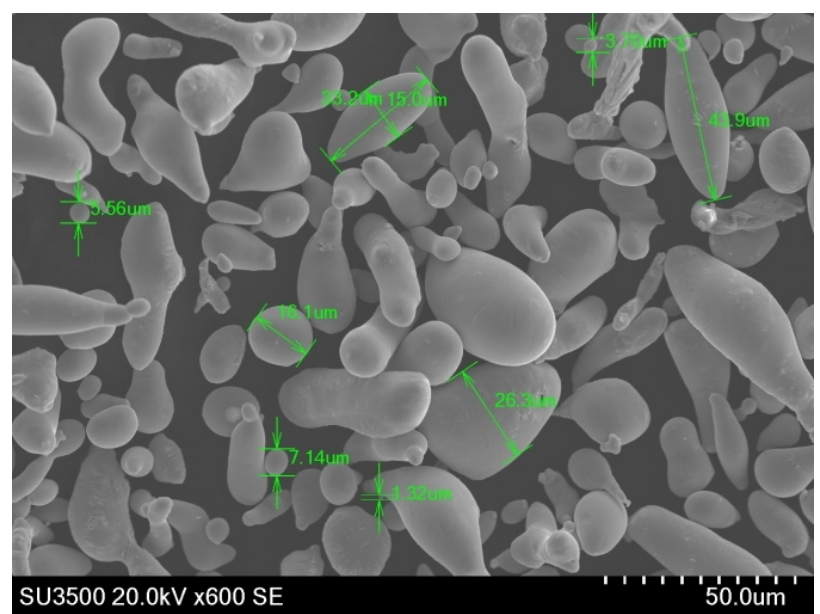

Gambar 6. Morfologi dari output powder berukuran antara 0 $37 \mu \mathrm{m}$ yang dihasilkan dari metode atomisasi gas - satu nosel gas dengan sudut $5^{\circ}$

Bentuk partikel powder timah yang dihasilkan didominasi oleh bentuk tidak bulat (sebesar 95\%), dikarenakan tumbukan atomisasi dari gas hanya berasal dari satu arah, sehingga membuat tetesan leburan timah teratomisasi dari satu arah dan pada posisi tertentu saja (Gambar 7a dan 7b). Leburan timah mengalir kebawah menuju mulut dari nosel gas, maka leburan timah langsung terdorong kedepan oleh tekanan gas, dimana arah tumbukan terhadap leburan timah tersebut hanya dari satu arah saja, sehingga leburan timah mengalami pemadatan menjadi lonjong (tidak bulat). Hasil yang berbeda akan didapat, jika leburan timah tertumbuk dan/atau teratomisasi dari berbagai arah pada titik yang sama, dengan aliran gas atomisasi membentuk pola melingkar, seperti proses powderisasi dengan menggunakan nosel atomisasi gas pada paten kami No. P00201911864.

Tekanan gas yang mengalir tidak konstan karena aliran gas dalam desain ini bekerja dengan sistem kompressor, sehingga ada jeda dalam proses aliran gas, pada saat menarik (input) dan mengalirkan (output) gas dari sistem kompresor, adapun proses ini terjadi dalam hitungan detik, sehingga sulit teramati, namun dari Gambar 3 (a-b) dan (c-e) dapat dilihat terjadi perubahan nilai tekanan gas pada saat dialirkan dalam proses atomisasi. Hal ini ditunjukkan oleh warna dari aliran gas yang berbeda (dapat dilihat pada bar warna pada gambar), dengan warna merah merupakan representasi dari tekanan gas dengan nilai tertinggi, sedangkan warna biru merupakan representasi dari tekanan gas dengan nilai terendah. Tekanan gas yang tidak stabil ini dapat menghasilkan powder dengan bentuk tidak teratur (Aryanto et al., 2019).

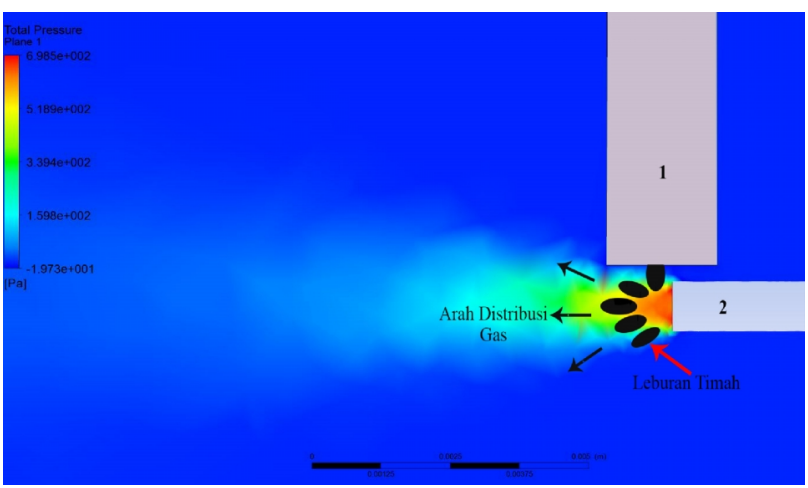

(a)

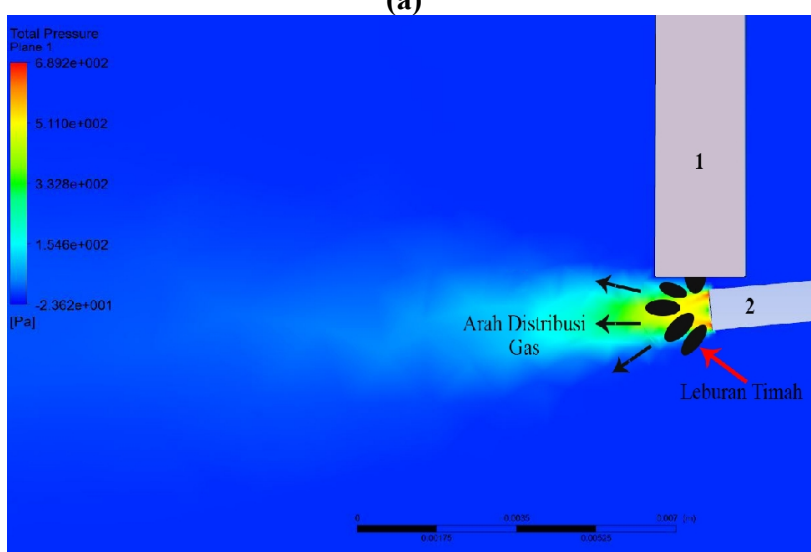

(b)

Gambar 7. Ilustrasi dari proses atomisasi oleh gas terhadap leburan timah dengan desain sudut antara nosel gas terhadap mulut nosel ruang peleburan (a) sudut $0^{\circ}$ dan (b) sudut $5^{\circ}$, dengan (1) ruang peleburan timah dan (2) nosel gas

\section{Kesimpulan}

Desain atomisasi gas - satu nosel gas dengan sudut nosel gas $5^{\circ}$ lebih efisien daripada sudut nosel gas $0^{\circ}$. Desain ini menghasilkan powder sebesar $88 \%$ dari input, dengan distribusi ukuran powder sebanyak 70,32\% berukuran 37 - $149 \mu \mathrm{m}$ dan sebanyak $29,68 \%$ berukuran $0-37 \mu \mathrm{m}$. Selain itu, powder yang dihasilkan didominasi oleh bentuk yang tidak teratur dan tersusun oleh fasa tunggal, yaitu fasa timah, dengan tidak dijumpai keberadaan fasa timah oksida pada semua ukuran powder.

\section{Ucapan terima kasih}

Peneliti mengucapkan terimakasih kepada Pusat Penelitian Fisika - LIPI, PT. Timah Industri, dan Kementerian Riset dan Teknologi, yang telah memberikan bantuan berupa fasilitas pengujian, bahan baku dan dana penelitian. Selain itu, peneliti juga mengucapkan terimakasih kepada Ibu Ressa Octavianty, Ph.D (Teknik Penerbangan - IULI) yang telah memberikan saran dalam pembuatan simulasi numerik pada penelitian ini. Peneliti juga mengucapkan terimakasih kepada Dr. Agus Sukarto Wismogroho atas bimbingan beliau dalam penulisan paper ini. 


\section{Daftar pustaka}

Akkas, M., Boz, M., 2019. Investigation of the compressibility and sinterabilty of AZ91 powder production and particle production by gas atomisation method. J. Magnes. Alloy. https://doi.org/10.1016/j.jma.2019.05.007

Antony, L.V.M., Reddy, R.G., 2003. Processes for production of high-purity metal powders. Jom 55, 14-18. https://doi.org/10.1007/s11837-003-0153-4

Aryanto, D., Wismogroho, A.S., Widayatno, W.B., Basyir, A., 2019. Pengembangan teknologi powderisasi timah lokal dengan metode atomisasi untuk produk pasta solder elektronika. Lap. Akhir Penelit. Ind. Probl. Solving 2019.

Bai, H.X., 2009. Low temperature synthesis of $\mathrm{SnO} 2$ nanocrystals from tin, sulfur and ammonium chloride powders. Mater. Lett. 63, 221-223. https://doi.org/10.1016/j.matlet.2008.09.040

Bastow, E., 2017. Does solder particle size impact the electrical reliability of a no-clean solder paste flux residue ? Indium Corp. Tech. Pap. 1-8.

Basyir, A., Aryanto, D., Wismogroho, A.S., Widayatno, W.B., 2020a. Effect of hot isostatic pressing method to enhance quality of tin powder. AIP Conf. Proc. 030021. https://doi.org/https://doi.org/10.1063/5. 0014653

Basyir, A., Asri, N.S., Aryanto, D., 2020b. Sn-CuOArabic Gum composition for red tracer projectile ammunition candidate. Submitted.

Champion, D., Britt, A., 2018. Australian resource reviews: tin 2018. Geoscience Australia.

Ciftci, N., Ellendt, N., Soares Barreto, E., Mädler, L., Uhlenwinkel, V., 2018. Increasing the amorphous yield of $\{(\mathrm{Fe} 0.6 \mathrm{Co} 0.4) 0.75 \mathrm{~B} 0.2 \mathrm{Si} 0.05\} 96 \mathrm{Nb} 4$ powders by hot gas atomization. Adv. Powder Technol. https://doi.org/10.1016/j.apt.2017.11.025

Ding, P., Mao, A., Zhang, X., Jin, X., Wang, B., Liu, M., Gu, X., 2017. Preparation, characterization and properties of multicomponent $\mathrm{AlCoCrFeNi2} .1$ powder by gas atomization method. J. Alloys Compd. 721, 609-614. https://doi.org/10.1016/j.jallcom. 2017.06.020

Dunkley, J.J., 1986. Powder metal technologies and application. ASM International.

Entezarian, M., Allaire, F., Tsantrizos, P., Drew, R.A.L., 1996. Plasma atomization: A new process for the production of fine, spherical powders. J. Miner. Met. Mater. Soc. 48, 53-55. https://doi.org/10.1007/ BF03222969

Hussain, S., Cui, C., He, L., Mädler, L., Uhlenwinkel, V., 2020. Effect of hot gas atomization on spray forming of steel tubes using a close-coupled atomizer (CCA). J. Mater. Process. Technol. 282, 116677. https://doi.org/10.1016/j.jmatprotec.2020.116677

IPC J-STD-005A, 2012. Requirements for Soldering Pastes, IPC International.

Islam, M.H., Paul, M.T.Y., Burheim, O.S., Pollet, B.G., 2019. Recent developments in the sonoelectrochemical synthesis of nanomaterials. Ultrason. Sonochem. 59. https://doi.org/10.1016/ j.ultsonch.2019.104711

Krammer, O., Gyarmati, B., Szilagyi, A., Illes, B., Busek, D., Dusek, K., 2018. The effect of solder paste particle size on the thixotropic behaviour during stencil printing. J. Mater. Process. Technol. 262, 571-576. https://doi.org/10.1016/j.jmatprotec.2018. 07.027

Lentz, T., 2019. Size matters: the effects of solder powder size on solder paste performance. SMT007 Mag. 32-55.

Li, X. gang, Zhu, Q., Shu, S., Fan, J. zhong, Zhang, S. ming, 2019. Fine spherical powder production during gas atomization of pressurized melts through melt nozzles with a small inner diameter. Powder Technol. https://doi.org/10.1016/j.powtec.2019.09.023

Li, Z., Huang, J., Zhang, Z., Zhao, F., Wu, Y., 2018. Preparation of high purity nano-silicon powders by direct current arc plasma evaporation method. Mater. Sci. Eng. B Solid-State Mater. Adv. Technol. 229, 612. https://doi.org/10.1016/j.mseb.2017.12.013

Lv, X., Liu, Z., Lei, T., Li, Q., Zhao, F., Peng, K., Ren, Y., Lu, S., Nong, B., 2019. Microstructure and properties of $\mathrm{Cu}-\mathrm{Cr}-\mathrm{Nb}$ alloy powder prepared by argon gas atomization. Adv. Powder Technol. https://doi.org/10.1016/j.apt.2019.07.013

Mulqueen, T., Pearce, J., 2018. ITA survey shows weaker tin use growth in 2018. International TIN Association.

Neikov, O.D., 2008. Handbook of non-ferrous metal powder: atomization and granulation. Elsevier.

Nobari, A.H., St-Laurent, S., 2016. Effect of fine and ultra-fine lead-free solder powder characteristics on the reflow property of pastes. SMTA Int. Proc. 327333.

Park, J.M., Na, T.W., Park, H.K., Yang, S.M., Gang, J.W., Lee, T.W., 2019. Preparation and characterization of spherical niobium silicide-based powder particles by electrode induction gas atomization. Mater. Lett. 243, 5-8. https://doi.org/ 10.1016/j.matlet.2019.01.155

Sun, P., Fang, Z.Z., Xia, Y., Zhang, Y., Zhou, C., 2016. A novel method for production of spherical Ti-6Al$4 \mathrm{~V}$ powder for additive manufacturing. Powder Technol. 301, 331-335. https://doi.org/10.1016/j. powtec.2016.06.022

Sun, P., Fang, Z.Z., Zhang, Y., Xia, Y., 2017. Review of the methods for production of spherical $\mathrm{Ti}$ and $\mathrm{Ti}$ alloy powder. Jom 69, 1853-1860. https://doi.org/10. 1007/s11837-017-2513-5

Wisnu, T., 2019. Analisa penerapan metode atomisasi air terhadap karakteristik serbuk alumunium. Anal. Penerapan Metod. At. Air Terhadap Karakteristik Serbuk Alumunium 1, 41-48.

Xiao, H., Zhang, Y.C., 2008. In air synthesis of SnS2 nanoplates from tin, sulfur and ammonium chloride powders. Mater. Chem. Phys. 112, 742-744. https://doi.org/10.1016/j.matchemphys.2008.07.119

Zhang, F.W., He, H.J., Wang, Z.G., Lin, G., Zhu, J., Zhang, J.S., Zhang, S.M., 2020. Solder paste metamorphism. Rare Met. https://doi.org/10.1007/ s12598-019-01356-6 